February 2018

\title{
The State of Social Media in Canada 2017
}

By Anatoliy Gruzd, Jenna Jacobson, Philip Mai, and Elizabeth Dubois

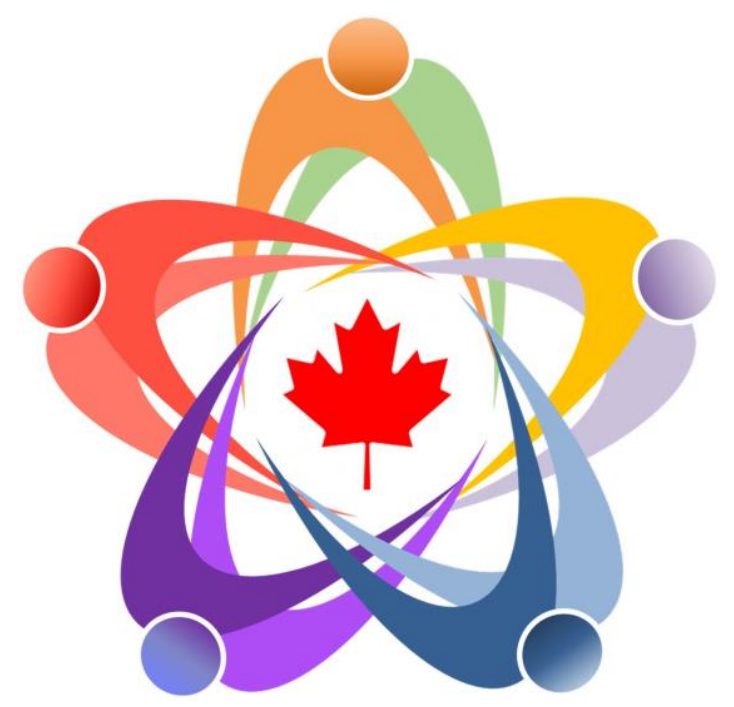

FOR MEDIA OR OTHER INQUIRIES:

Philip Mai, Director of Business

and Communications

416-979-5000 ext. 3509

philip.mai@ryerson.ca

\section{Ryerson}

University

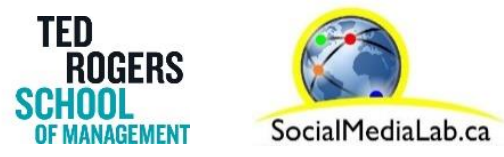

RECOMMENDED CITATION: Gruzd, Jacobson, Mai, \& Dubois. (2018). The State of Social Media in Canada 2017. Version: 1.0. Ryerson University Social Media Lab. DOI:10.5683/SP/AL8Z6R 


\section{Table of Contents}

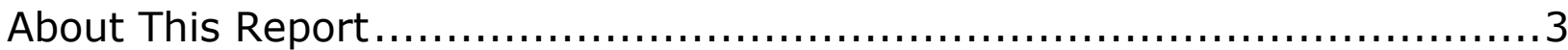

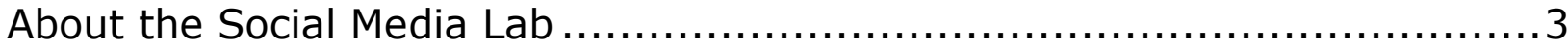

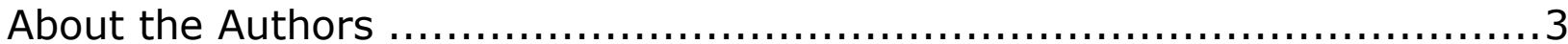

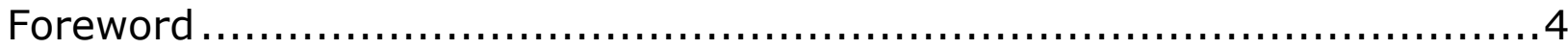

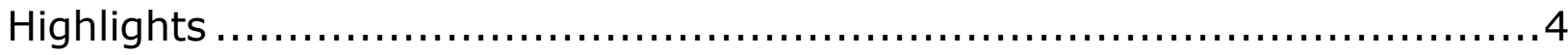

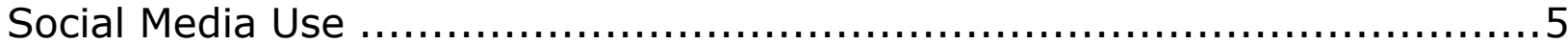

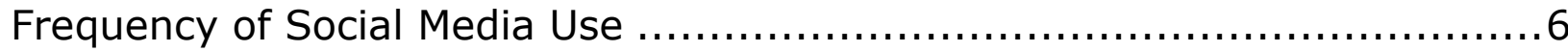

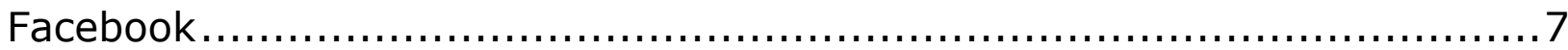

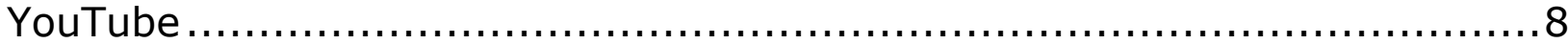

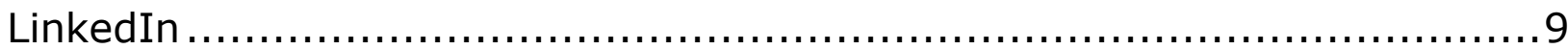

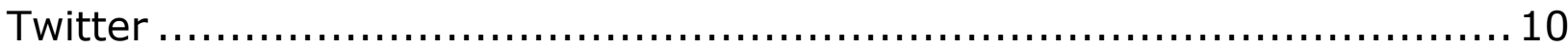

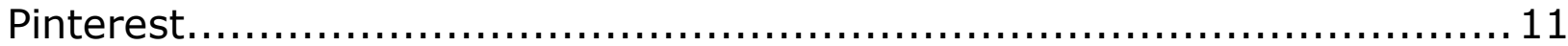

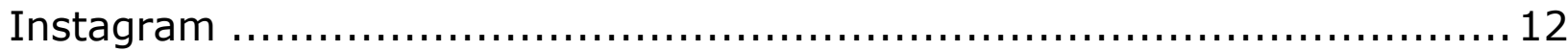

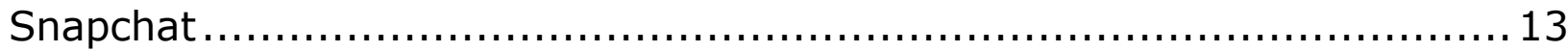

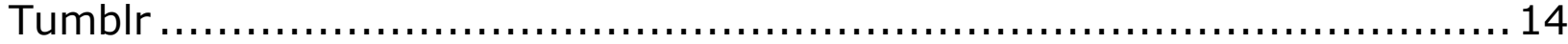

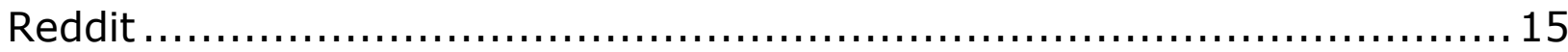

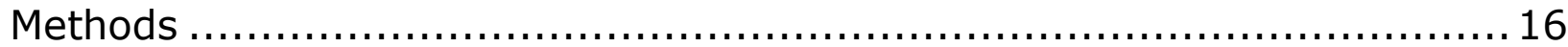

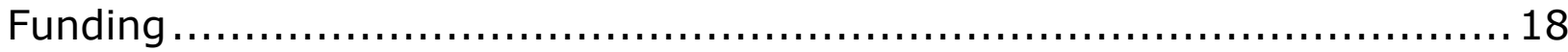

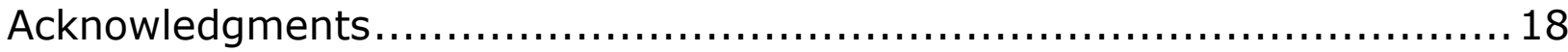




\section{About This Report}

This report was produced by the Social Media Lab (SocialMediaLab.ca) at Ted Rogers School of Management, Ryerson University and is part of the Social Media Data Stewardship Project (SocialMediaData.org). The report was written by Anatoliy Gruzd, Jenna Jacobson, Philip Mai, and Elizabeth Dubois. It is based on a censusbalanced online survey of 1,500 online Canadian adults conducted between June 1-July 15, 2017.

\section{About the Social Media Lab}

The Social Media Lab is an interdisciplinary research laboratory at Ted Rogers School of Management at Ryerson University. The lab studies how social media is changing the ways in which people communicate, share information, conduct business and form communities, and how these changes impact society. The broad aims of the lab's research initiatives are to provide decision makers with additional knowledge and insights into the behaviours and relationships of online network members, and understand how these interpersonal connections influence our choices and actions.

(C) Social Media Lab 2018

\section{About the Authors}

Anatoliy Gruzd, PhD is a Canada Research Chair (CRC), Associate Professor and Director of Research at the Social Media Lab at Ted Rogers School of Management, Ryerson University. He is the Co-Editor of the SAGE journal Big Data \& Society and Member of the Royal Society of Canada's College of New Scholars, Artists and Scientists.

Jenna Jacobson, PhD is a Postdoctoral Fellow at the Social Media Lab at Ryerson University and is a CoChair of the International Conference on Social Media \& Society.

Philip Mai, JD is the Director of Business and Communications at the Social Media Lab at Ryerson University, Manager of Academic Communications at Ryerson University, and a CoFounder of the International Conference on Social Media \& Society.

Elizabeth Dubois, PhD is an Assistant Professor at the Department of Communication and Faculty Member at the Centre for Law, Technology and Society, University of Ottawa, a Fellow at the Public Policy Forum of Canada, and a long-time collaborator of the Social Media Lab at Ryerson University. 


\section{Foreword}

Today, billions of people around the world are turning to social media to socialize, conduct business, keep up with the news, as well as discover, discuss, and share information. The significance of this global adoption of a relatively new communication and information technology cannot be overlooked.

As a country, Canada has one of the most connected populations in the world. For many Canadians, social media is now a part of their daily routine. Our survey results show that an overwhelming majority of online Canadian adults (94\%) have an account on at least one social media platform. This makes it critical for policy makers, researchers, and others to have a better grasp of what social media platforms Canadians are using to connect and converse with one another.

This report provides a snapshot of the social media usage trends and patterns amongst online Canadian adults based on an online survey of 1,500 participants (see Methods on p. 16 for more details).

\section{Highlights}

- Facebook is the most popular social media platform in Canada; $84 \%$ of online Canadian adults report having a Facebook account, followed by YouTube (59\%) and LinkedIn (46\%)-See pp. 7-9.

- Facebook also has the highest percentage of daily users $(79 \%)$, followed by Instagram (61\%) and Snapchat (60\%)-See p. 6.

- Facebook is the only social media platform where the oldest generation (55+) crosses the $50 \%$ adoption mark (75\%)-See p. 7.

- Young people aged 18-24 are the largest adopters of social media (except for LinkedIn and Pinterest)-See pp. 7-15.

- Women have adopted most social media platforms in higher proportions than men (except for YouTube, LinkedIn, and Reddit)See pp. 7-15.

- Pinterest is the second most popular platform for women (56\%) after Facebook (88\%)-See p. 7 and 11.

- LinkedIn is particularly popular with those who are self-employed (56\%)-See p. 9.

- Canadians in the highest household income group $(\$ 120,000+)$ are more likely to have an account on LinkedIn, as well as Twitter, than those who are less wealthy-See pp. 9-10.

- While the number of online Canadians on Reddit is relatively small $(9 \%)$, those who do use the platform visit it regularly $(57 \%$ daily)-See p. 6 and 15. 


\section{Social Media Use}

Percentage of online Canadian adults with an account on the following platforms:

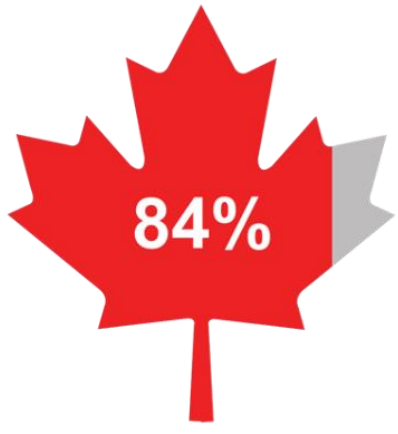

Facebook

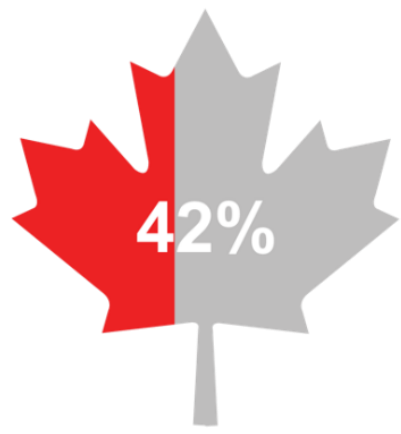

Twitter

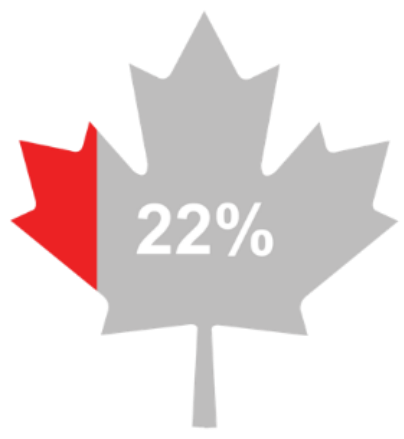

Snapchat

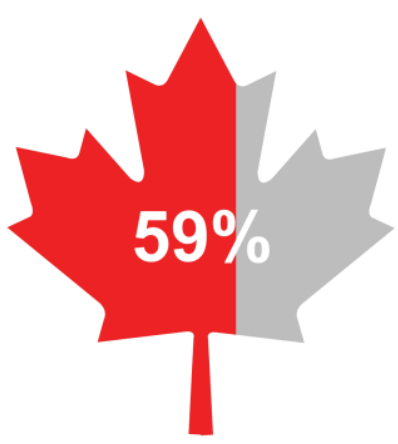

YouTube

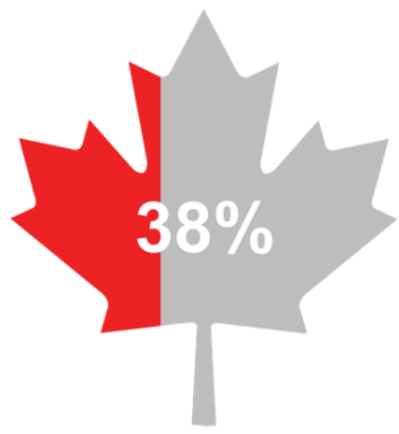

Pinterest

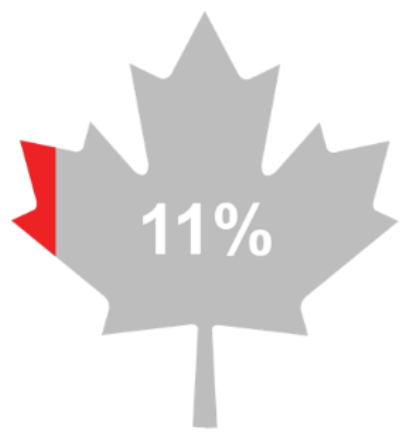

Tumblr

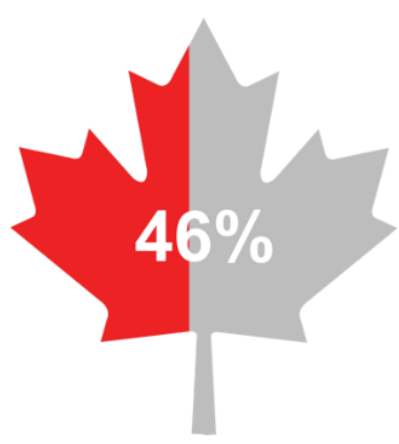

LinkedIn

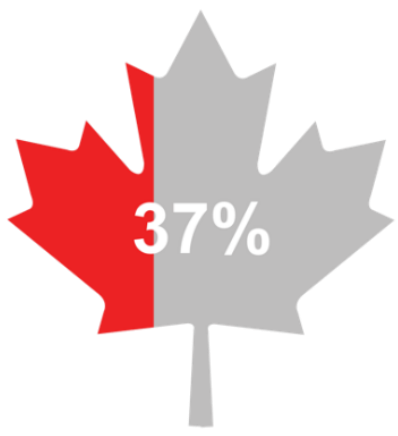

Instagram

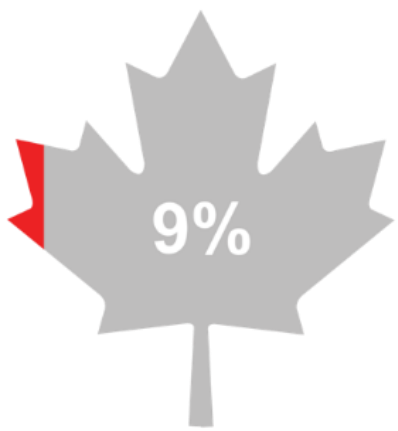

Reddit

Source: Survey conducted June 1-July 15, 2017.

"State of Social Media in Canada 2017"

Ryerson University Social Media Lab 


\section{Frequency of Social Media Use}

Facebook is the most widely used social media platform in Canada, and it is also the platform that has the highest percentage of daily users amongst the nine platforms detailed in this survey. $79 \%$ of Facebook users visit the platform daily ( $48 \%$ visit several times a day and $30 \%$ visit daily ${ }^{1}$ ).

Instagram (61\% daily), Snapchat ( $60 \%$ daily), and Reddit ( $57 \%$ daily) comprise the second category of the most daily frequented platforms with over half the users of each platform visiting daily. While the number of online Canadians on Reddit is relatively small $(9 \%)$, those who do use the platform visit it regularly.

YouTube ( $48 \%$ daily), Twitter (45\% daily), and Tumblr ( $40 \%$ daily) are in the third category with close to half of users visiting the platforms daily.

Finally, Pinterest $(28 \%$ daily) and LinkedIn (20\% daily) trail behind with the lowest daily use.
Amongst users of each

platform, frequency of use (\%)

घDaily 口Weekly uLess Often

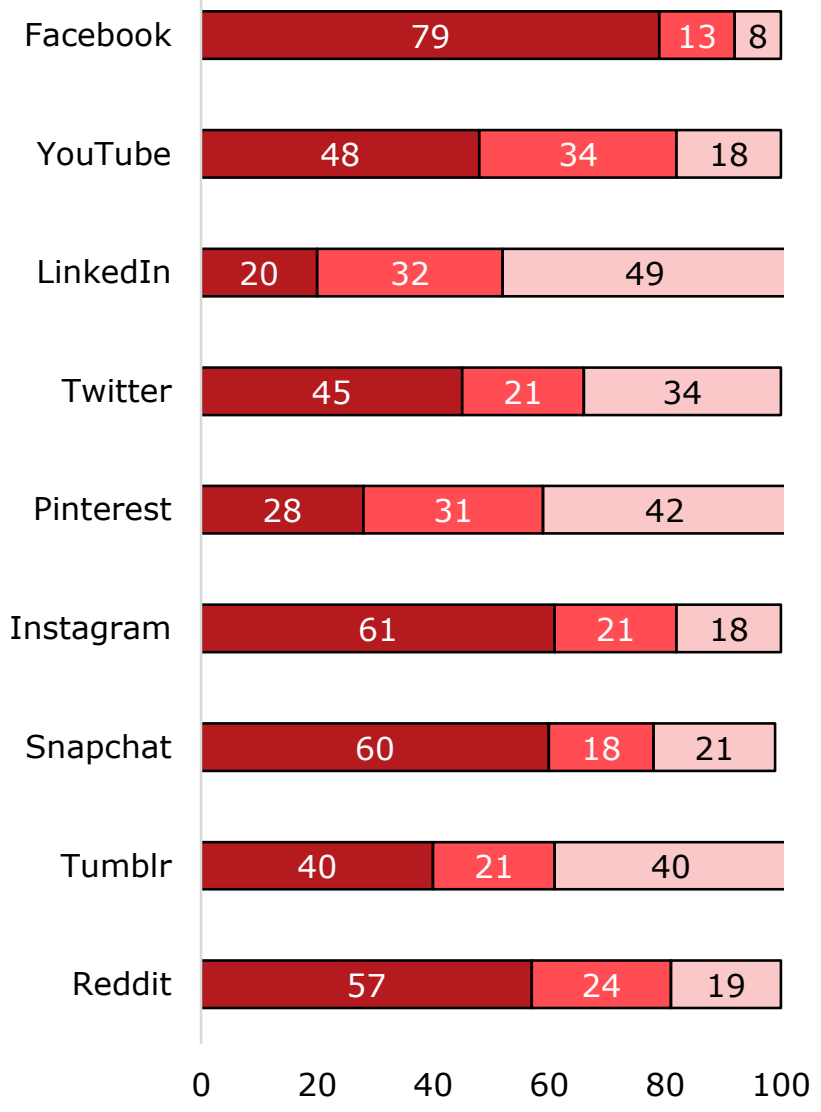

Note: All numbers are rounded to the nearest $1 \%$. Source: Survey conducted June 1-July 15, 2017. "State of Social Media in Canada 2017" Ryerson University Social Media Lab

1 The $1 \%$ difference is due to rounding. 


\section{Facebook}

Facebook dominates the social media landscape; $84 \%$ of online Canadian adults report having a Facebook account making it the most widely adopted platform in Canada. Beyond adoption, Canadians are also the most active on this platform with $80 \%$ of people being Monthly Active Users (MAU). Women (88\%) are more likely to use Facebook than men ( $81 \%)$.

Facebook adoption is almost ubiquitous with young people aged 18-24 (95\%); three-quarters of those $55+$ years old (75\%) are also on Facebook. In fact, this is the only platform where the oldest generation crosses the 50\% adoption and monthly usage mark.

Facebook adoption is consistently high across all income groups-ranging from $80 \%$ to $88 \%$. Those with the least education (75\%) are less likely to be on Facebook.

Canadians who are not employed (77\%) have the lowest adoption, whereas those who work full-time $(90 \%)$ have the highest adoption of Facebook.

\section{$84 \%$ of online Canadian adults have a Facebook account}

\begin{tabular}{|c|c|c|}
\hline & Total & $\begin{array}{r}\text { Monthly } \\
\text { Active Users }\end{array}$ \\
\hline All Online Adults & $84 \%$ & $80 \%$ \\
\hline Female & 88 & 85 \\
\hline Male & 81 & 75 \\
\hline $18-24$ & 95 & 88 \\
\hline $25-34$ & 94 & 92 \\
\hline $35-44$ & 92 & 89 \\
\hline $45-55$ & 83 & 80 \\
\hline $55+$ & 75 & 69 \\
\hline Less than $\$ 20 \mathrm{~K} /$ year & 82 & 77 \\
\hline$\$ 20 K$ to $\$ 39,999$ & 80 & 77 \\
\hline$\$ 40 \mathrm{~K}$ to $\$ 59,999$ & 87 & 82 \\
\hline$\$ 60 \mathrm{~K}$ to $\$ 79,999$ & 84 & 81 \\
\hline$\$ 80 \mathrm{~K}$ to $\$ 99,999$ & 86 & 83 \\
\hline$\$ 100 \mathrm{~K}$ to $\$ 119,999$ & 88 & 83 \\
\hline$\$ 120,000+$ & 82 & 78 \\
\hline Some school & 75 & 75 \\
\hline High school & 84 & 80 \\
\hline Some college & 85 & 79 \\
\hline College diploma & 83 & 79 \\
\hline Bachelor's & 85 & 81 \\
\hline Master's & 85 & 83 \\
\hline Professional degree & 93 & 87 \\
\hline Doctorate & 81 & 74 \\
\hline Full-time & 90 & 86 \\
\hline Part-time & 85 & 82 \\
\hline Self-employed & 78 & 72 \\
\hline Not employed & 77 & 73 \\
\hline
\end{tabular}




\section{YouTube}

YouTube is the second most popular social media platform in Canada; $59 \%$ of online adults report having an account on the platform. Canadians are active users of the video-sharing platform with the majority of users being Monthly Active Users (54\%). Aside from Facebook, this is the only platform where the MAU is above $50 \%$.

Unlike Facebook, men (62\%) are more likely to have an account on YouTube than women $(55 \%)$. There is a large distribution of use across the age groups, but adoption lowers with age; $41 \%$ of those $55+$ have a YouTube account. $90 \%$ of young people aged 18-24 have an account on YouTube and almost the same percentage use the platform at least monthly (88\%).

YouTube adoption is relatively consistent across income groupsranging from $55 \%$ of those who have an annual household income of $\$ 100,000-\$ 119,999$ to $65 \%$ of those in the lowest income group.

Those with the lowest education (46\%) and those not employed (49\%) are least likely to have a YouTube account.

\section{$59 \%$ of online Canadian adults have a YouTube account}

Total Monthly Active Users

\begin{tabular}{|c|c|c|}
\hline All Online Adults & $59 \%$ & $54 \%$ \\
\hline Female & 55 & 50 \\
\hline Male & 62 & 58 \\
\hline $18-24$ & 90 & 88 \\
\hline $25-34$ & 79 & 76 \\
\hline $35-44$ & 64 & 59 \\
\hline $45-55$ & 55 & 50 \\
\hline $55+$ & 41 & 36 \\
\hline Less than $\$ 20 \mathrm{~K} /$ year & 65 & 62 \\
\hline$\$ 20 K$ to $\$ 39,999$ & 57 & 55 \\
\hline$\$ 40 \mathrm{~K}$ to $\$ 59,999$ & 60 & 54 \\
\hline$\$ 60 \mathrm{~K}$ to $\$ 79,999$ & 57 & 53 \\
\hline$\$ 80 \mathrm{~K}$ to $\$ 99,999$ & 61 & 57 \\
\hline$\$ 100 \mathrm{~K}$ to $\$ 119,999$ & 55 & 52 \\
\hline$\$ 120,000+$ & 58 & 52 \\
\hline Some school & 46 & 42 \\
\hline High school & 56 & 51 \\
\hline Some college & 58 & 54 \\
\hline College diploma & 58 & 54 \\
\hline Bachelor's & 62 & 58 \\
\hline Master's & 58 & 54 \\
\hline Professional degree & 53 & 49 \\
\hline Doctorate & 59 & 48 \\
\hline Full-time & 65 & 61 \\
\hline Part-time & 60 & 55 \\
\hline Self-employed & 56 & 49 \\
\hline Not employed & 49 & 46 \\
\hline
\end{tabular}




\section{LinkedIn}

LinkedIn is the third most popular social media platform in Canada; $46 \%$ of online adults report having an account on the platform.

Almost half of the men (49\%) surveyed have a LinkedIn account, whereas women (44\%) are slightly less likely to have an account.

LinkedIn adoption is quite high across age groups, but those in the oldest age group of $55+(43 \%)$ and youngest age group of $18-24$ year olds ( $40 \%)$ have the lowest adoption rates.

Generally, the higher the level of education, the higher the LinkedIn adoption. High school graduates (21\%) have the lowest LinkedIn adoption, and individuals with a professional degree $(69 \%)$ have the highest adoption.

LinkedIn is particularly popular with those who are self-employed (56\%). In fact, this is the only platform where people who are self-employed comprise the highest user group, which makes sense considering that LinkedIn is a business- and employment-related social media platform.

\section{$46 \%$ of online Canadian adults have a LinkedIn account}

\begin{tabular}{|c|c|c|}
\hline & Total & $\begin{array}{l}\text { nthly } \\
\text { Users }\end{array}$ \\
\hline All Online Adults & $46 \%$ & $33 \%$ \\
\hline Female & 44 & 29 \\
\hline Male & 49 & 36 \\
\hline $18-24$ & 40 & 26 \\
\hline $25-34$ & 53 & 39 \\
\hline $35-44$ & 49 & 37 \\
\hline $45-55$ & 48 & 37 \\
\hline $55+$ & 43 & 28 \\
\hline Less than $\$ 20 \mathrm{~K} /$ year & 30 & 23 \\
\hline$\$ 20 K$ to $\$ 39,999$ & 34 & 21 \\
\hline$\$ 40 \mathrm{~K}$ to $\$ 59,999$ & 38 & 24 \\
\hline$\$ 60 \mathrm{~K}$ to $\$ 79,999$ & 51 & 35 \\
\hline$\$ 80 \mathrm{~K}$ to $\$ 99,999$ & 49 & 34 \\
\hline$\$ 100 \mathrm{~K}$ to $\$ 119,999$ & 53 & 39 \\
\hline$\$ 120,000+$ & 59 & 48 \\
\hline Some school & 25 & 21 \\
\hline High school & 21 & 11 \\
\hline Some college & 43 & 24 \\
\hline College diploma & 39 & 27 \\
\hline Bachelor's & 57 & 42 \\
\hline Master's & 66 & 54 \\
\hline Professional degree & 69 & 42 \\
\hline Doctorate & 59 & 48 \\
\hline Full-time & 54 & 41 \\
\hline Part-time & 39 & 23 \\
\hline Self-employed & 56 & 45 \\
\hline Not employed & 34 & 20 \\
\hline
\end{tabular}




\section{Twitter}

Twitter is the fourth most popular social media platform in Canada; $42 \%$ of online adults report having an account on the platform.

Men and women have similar adoption rates of Twitter; women (43\%) are slightly more likely than men (40\%) to have a Twitter account, but men are slightly more active users (33\% being Monthly Active Users) versus women (31\% being Monthly Active Users).

Older people are the least likely to adopt Twitter; only $27 \%$ of those $55+$ have a Twitter account. Young people aged $18-24(60 \%)$ and $25-34(59 \%)$ are the most prevalent user groups on Twitter.

Like LinkedIn, the wealthiest Canadians are more likely to adopt Twitter; $46 \%$ of those with an annual household income of $\$ 120,000+$ have a Twitter account.

Individuals with doctorates (33\%) have the lowest adoption rate of Twitter. Almost half of full-time workers (49\%) have a Twitter account, dropping to roughly a third amongst those who are not employed (31\%).

\section{$42 \%$ of online Canadian adults have a Twitter account}

\begin{tabular}{|c|c|c|}
\hline \multirow[b]{2}{*}{ All Online Adults } & \multicolumn{2}{|c|}{$\begin{array}{c}\text { Total } \begin{array}{r}\text { Monthly } \\
\text { Active Users }\end{array}\end{array}$} \\
\hline & $42 \%$ & $32 \%$ \\
\hline Female & 43 & 31 \\
\hline Male & 40 & 33 \\
\hline $18-24$ & 60 & 47 \\
\hline $25-34$ & 59 & 45 \\
\hline $35-44$ & 50 & 40 \\
\hline $45-55$ & 40 & 32 \\
\hline $55+$ & 27 & 20 \\
\hline Less than $\$ 20 \mathrm{~K} /$ year & 42 & 34 \\
\hline$\$ 20 K$ to $\$ 39,999$ & 36 & 26 \\
\hline$\$ 40 K$ to $\$ 59,999$ & 40 & 31 \\
\hline$\$ 60 \mathrm{~K}$ to $\$ 79,999$ & 39 & 31 \\
\hline$\$ 80 \mathrm{~K}$ to $\$ 99,999$ & 44 & 34 \\
\hline$\$ 100 \mathrm{~K}$ to $\$ 119,999$ & 45 & 37 \\
\hline$\$ 120,000+$ & 46 & 35 \\
\hline Some school & 46 & 29 \\
\hline High school & 36 & 28 \\
\hline Some college & 46 & 33 \\
\hline College diploma & 36 & 27 \\
\hline Bachelor's & 45 & 27 \\
\hline Master's & 47 & 39 \\
\hline Professional degree & 47 & 36 \\
\hline Doctorate & 33 & 26 \\
\hline Full-time & 49 & 39 \\
\hline Part-time & 47 & 36 \\
\hline Self-employed & 38 & 26 \\
\hline Not employed & 31 & 23 \\
\hline
\end{tabular}




\section{Pinterest}

$38 \%$ of online Canadians report having a Pinterest account. Of all social media platforms, Pinterest has the largest adoption difference between men $(18 \%)$ and women (56\%). Even though Pinterest is the fifth most popular platform for Canadians, it is the second most popular platform for online Canadian women with only Facebook having higher adoption.

Online adults aged 25-34 are the most prevalent user group on Pinterest with an adoption rate of $54 \%$, while those $55+$ are less likely to be on Pinterest with an adoption rate of $30 \%$.

Except for Canadians in the highest household income group, Pinterest adoption tends to increase with annual household income.

Based on education, a bell curve shape emerges with the highest rate of adoption amongst those who report having some college $(39 \%)$, college diploma (42\%), and bachelor's (39\%).

Like Twitter, YouTube, and Facebook, Canadians that are self-employed (28\%) and not employed (34\%) have the lowest Pinterest adoption.

\section{$38 \%$ of online Canadian adults have a Pinterest account}

\begin{tabular}{|c|c|c|}
\hline & Total & $\begin{array}{l}\text { onthly } \\
\text { Users }\end{array}$ \\
\hline All Online Adults & $38 \%$ & $29 \%$ \\
\hline Female & 56 & 44 \\
\hline Male & 18 & 14 \\
\hline $18-24$ & 45 & 32 \\
\hline $25-34$ & 54 & 43 \\
\hline $35-44$ & 37 & 29 \\
\hline $45-55$ & 38 & 28 \\
\hline $55+$ & 30 & 24 \\
\hline Less than $\$ 20 \mathrm{~K} /$ year & 34 & 25 \\
\hline$\$ 20 K$ to $\$ 39,999$ & 35 & 30 \\
\hline$\$ 40 \mathrm{~K}$ to $\$ 59,999$ & 36 & 28 \\
\hline$\$ 60 \mathrm{~K}$ to $\$ 79,999$ & 41 & 31 \\
\hline$\$ 80 \mathrm{~K}$ to $\$ 99,999$ & 40 & 31 \\
\hline$\$ 100 \mathrm{~K}$ to $\$ 119,999$ & 42 & 33 \\
\hline$\$ 120,000+$ & 36 & 25 \\
\hline Some school & 29 & 21 \\
\hline High school & 33 & 27 \\
\hline Some college & 39 & 29 \\
\hline College diploma & 42 & 33 \\
\hline Bachelor's & 39 & 30 \\
\hline Master's & 36 & 28 \\
\hline Professional degree & 31 & 20 \\
\hline Doctorate & 30 & 15 \\
\hline Full-time & 42 & 32 \\
\hline Part-time & 41 & 29 \\
\hline Self-employed & 28 & 24 \\
\hline Not employed & 34 & 26 \\
\hline
\end{tabular}




\section{Instagram}

As the sixth most popular social media platform in Canada, 37\% of online Canadians report having an Instagram account.

Women $(46 \%)$ are on Instagram at a much higher rate than men (28\%). Those with an Instagram account are active users with comparatively high Monthly Active Users across all demographic groups.

The youngest age group of 18-24 year olds $(67 \%)$ dominates Instagram, and high levels of adoption can also be found in the 25-34 year old group (62\%).

Almost half of Canadians with a Professional degree (47\%) have an Instagram account.

Those who work full-time (46\%) are almost twice as likely to have an Instagram account than those not employed (24\%).

\section{$37 \%$ of online Canadian adults have an Instagram account}

\begin{tabular}{|c|c|c|}
\hline & Total & $\begin{array}{r}\text { Monthly } \\
\text { Active Users }\end{array}$ \\
\hline All Online Adults & $37 \%$ & $33 \%$ \\
\hline Female & 46 & 41 \\
\hline Male & 28 & 24 \\
\hline $18-24$ & 67 & 65 \\
\hline $25-34$ & 62 & 58 \\
\hline $35-44$ & 45 & 42 \\
\hline $45-55$ & 32 & 25 \\
\hline $55+$ & 17 & 14 \\
\hline Less than $\$ 20 \mathrm{~K} /$ year & 43 & 38 \\
\hline$\$ 20 K$ to $\$ 39,999$ & 31 & 27 \\
\hline$\$ 40 \mathrm{~K}$ to $\$ 59,999$ & 35 & 30 \\
\hline$\$ 60 \mathrm{~K}$ to $\$ 79,999$ & 32 & 28 \\
\hline$\$ 80 \mathrm{~K}$ to $\$ 99,999$ & 38 & 35 \\
\hline$\$ 100 \mathrm{~K}$ to $\$ 119,999$ & 44 & 42 \\
\hline$\$ 120,000+$ & 40 & 35 \\
\hline Some school & 42 & 33 \\
\hline High school & 32 & 27 \\
\hline Some college & 37 & 31 \\
\hline College diploma & 37 & 34 \\
\hline Bachelor's & 39 & 36 \\
\hline Master's & 35 & 30 \\
\hline Professional degree & 47 & 42 \\
\hline Doctorate & 37 & 33 \\
\hline Full-time & 46 & 43 \\
\hline Part-time & 44 & 39 \\
\hline Self-employed & 26 & 22 \\
\hline Not employed & 24 & 20 \\
\hline
\end{tabular}




\section{Snapchat}

Roughly one quarter of online Canadians (22\%) report having a Snapchat account. Like Instagram and Pinterest, women (28\%) are more likely to adopt Snapchat than men $(16 \%)$.

Young people $18-24$ years old (66\%) and 25-34 years old (46\%) are the largest user groups on the platform. They are also active on the platform with $62 \%$ and $39 \%$ being Monthly Active Users, respectively.

Adoption is relatively consistent across income groups-ranging from $19 \%$ to $26 \%$. Snapchat adoption does not follow a predictable pattern in terms of education-ranging from $11 \%$ amongst those with a doctorate to $26 \%$ amongst those with a bachelor's.

There is a large difference in adoption rates between those who work full-time $(29 \%)$ or part-time $(29 \%)$ and those who are self-employed $(10 \%)$ or not employed (13\%).

\section{$22 \%$ of online Canadian adults have a Snapchat account}

Total Monthly Active Users

\begin{tabular}{|c|c|c|}
\hline All Online Adults & $22 \%$ & $19 \%$ \\
\hline Female & 28 & 25 \\
\hline Male & 16 & 12 \\
\hline $18-24$ & 66 & 62 \\
\hline $25-34$ & 46 & 39 \\
\hline $35-44$ & 19 & 15 \\
\hline $45-55$ & 13 & 11 \\
\hline $55+$ & 5 & 3 \\
\hline Less than $\$ 20 \mathrm{~K} /$ year & 24 & 18 \\
\hline$\$ 20 K$ to $\$ 39,999$ & 19 & 16 \\
\hline$\$ 40 \mathrm{~K}$ to $\$ 59,999$ & 24 & 22 \\
\hline$\$ 60 \mathrm{~K}$ to $\$ 79,999$ & 20 & 17 \\
\hline$\$ 80 \mathrm{~K}$ to $\$ 99,999$ & 21 & 18 \\
\hline$\$ 100 \mathrm{~K}$ to $\$ 119,999$ & 26 & 22 \\
\hline$\$ 120,000+$ & 22 & 19 \\
\hline Some school & 25 & 17 \\
\hline High school & 18 & 17 \\
\hline Some college & 24 & 20 \\
\hline College diploma & 20 & 17 \\
\hline Bachelor's & 26 & 23 \\
\hline Master's & 18 & 16 \\
\hline Professional degree & 22 & 16 \\
\hline Doctorate & 11 & 11 \\
\hline Full-time & 29 & 26 \\
\hline Part-time & 29 & 27 \\
\hline Self-employed & 10 & 8 \\
\hline Not employed & 13 & 9 \\
\hline
\end{tabular}




\section{Tumblr}

Roughly one-in-ten online Canadian adults $(11 \%)$ report having a Tumblr account.

Women (13\%) are slightly more likely than men (7\%) to be on Tumblr.

18-24 year olds (36\%) are almost twice as likely to adopt the platform as 25-34 year olds (17\%); Tumblr adoption drops to $10 \%$ or below for those 35 years old and older.

Tumblr is most popular amongst those in the lowest household income group $(16 \%)$. In comparison, those who earn $\$ 100,000-\$ 119,00 \quad(8 \%) \quad$ and $\$ 120,000+(8 \%)$ are half as likely to have a Tumblr account.

People who work part-time (20\%) are more likely to be on Tumblr than those who work full-time $(12 \%)$, are selfemployed $(3 \%)$, or are not employed $(8 \%)$. Tumblr is the only platform where adoption is higher amongst parttime workers than full-time workers.

\section{$11 \%$ of online Canadian adults have a Tumblr account}

\begin{tabular}{|c|c|c|}
\hline & Total & $\begin{array}{l}\text { ithly } \\
\text { Isers }\end{array}$ \\
\hline All Online Adults & $11 \%$ & $8 \%$ \\
\hline Female & 13 & 9 \\
\hline Male & 7 & 6 \\
\hline $18-24$ & 36 & 27 \\
\hline $25-34$ & 17 & 12 \\
\hline $35-44$ & 10 & 6 \\
\hline $45-55$ & 6 & 6 \\
\hline $55+$ & 3 & 2 \\
\hline Less than $\$ 20 \mathrm{~K} /$ year & 16 & 12 \\
\hline$\$ 20 K$ to $\$ 39,999$ & 12 & 6 \\
\hline$\$ 40 \mathrm{~K}$ to $\$ 59,999$ & 10 & 8 \\
\hline$\$ 60 \mathrm{~K}$ to $\$ 79,999$ & 10 & 7 \\
\hline$\$ 80 \mathrm{~K}$ to $\$ 99,999$ & 12 & 9 \\
\hline$\$ 100 \mathrm{~K}$ to $\$ 119,999$ & 8 & 6 \\
\hline$\$ 120,000+$ & 8 & 7 \\
\hline Some school & 8 & 4 \\
\hline High school & 10 & 8 \\
\hline Some college & 9 & 3 \\
\hline College diploma & 9 & 6 \\
\hline Bachelor's & 13 & 11 \\
\hline Master's & 10 & 8 \\
\hline Professional degree & 11 & 9 \\
\hline Doctorate & 11 & 11 \\
\hline Full-time & 12 & 9 \\
\hline Part-time & 20 & 15 \\
\hline Self-employed & 3 & 1 \\
\hline Not employed & 8 & 5 \\
\hline
\end{tabular}




\section{Reddit}

Less than one-in-ten online Canadian adults ( $9 \%)$ are on Reddit. Of the nine social media platforms detailed in this research, Reddit has the smallest population of users-meaning the platform remains niche in use across Canadian demographic groups.

$10 \%$ of men and $8 \%$ of women report having a Reddit account.

Reddit's users are largely comprised of young people. Over one-quarter of young people aged 18-24 (28\%) have a Reddit account with the adoption rate dramatically dropping in the older age groups (only $2 \%$ amongst those $55+$ ).

Reddit users are relatively equally distributed across income groups with slightly higher adoption rates in the higher income groups. $11 \%$ of those with $\$ 120,000+$ annual household income have a Reddit account; those with less than $\$ 20,000$ annual household income have the lowest adoption (3\%).

Canadians who are employed full-time $(12 \%)$ or part-time $(11 \%)$ are more than twice as likely to adopt Reddit as those self-employed $(5 \%)$ or not employed (5\%).

\section{9\% of online Canadian adults have a Reddit account}

\begin{tabular}{|c|c|c|}
\hline & Total & $\begin{array}{l}\text { athly } \\
\text { Jsers }\end{array}$ \\
\hline All Online Adults & $9 \%$ & $8 \%$ \\
\hline Female & 8 & 7 \\
\hline Male & 10 & 9 \\
\hline $18-24$ & 28 & 26 \\
\hline $25-34$ & 16 & 15 \\
\hline $35-44$ & 8 & 8 \\
\hline $45-55$ & 7 & 6 \\
\hline $55+$ & 2 & 2 \\
\hline Less than $\$ 20 \mathrm{~K} /$ year & 3 & 3 \\
\hline$\$ 20 K$ to $\$ 39,999$ & 8 & 8 \\
\hline$\$ 40 \mathrm{~K}$ to $\$ 59,999$ & 8 & 8 \\
\hline$\$ 60 \mathrm{~K}$ to $\$ 79,999$ & 9 & 8 \\
\hline$\$ 80 \mathrm{~K}$ to $\$ 99,999$ & 11 & 9 \\
\hline$\$ 100 \mathrm{~K}$ to $\$ 119,999$ & 9 & 9 \\
\hline$\$ 120,000+$ & 11 & 10 \\
\hline Some school & 0 & 0 \\
\hline High school & 7 & 7 \\
\hline Some college & 10 & 10 \\
\hline College diploma & 8 & 7 \\
\hline Bachelor's & 11 & 10 \\
\hline Master's & 8 & 8 \\
\hline Professional degree & 11 & 9 \\
\hline Doctorate & 7 & 0 \\
\hline Full-time & 12 & 11 \\
\hline Part-time & 11 & 9 \\
\hline Self-employed & 5 & 5 \\
\hline Not employed & 5 & 4 \\
\hline
\end{tabular}




\section{Methods}

Data was collected using a market research data company, Research Now, for panel recruitment. The survey was open from June 1 to July 15, 2017 and was hosted by Qualtrics. We received a total of 1,500 completed responses after data cleaning. The survey was made available to online Canadian adults in French and English. The term "online Canadian adults" refers to Internet users aged 18 and older.

To increase the representativeness of the data, we used quota sampling by age, gender, and geographical region to match the distributions in the 2016 Statistics Canada Census ${ }^{2}$. We recognize gender is not binary; however, the sampling question was phrased to be in line with Statistics Canada for recruiting a representative sample of adult Canadians. Later in the survey, participants were invited to self-identify as "trans*, non-binary, two-spirit, genderqueer, or other" and $0.8 \%$ (12 people) did. Considering the small and non-representative sample of this group, the gender-based distributions are only reported based on the counts of participants who selfidentified as female or male. Four respondents were excluded from the demographic-based counts due to their incomplete demographic data.

\section{Census-balanced Sampling by Gender, Age, and Region}

\begin{tabular}{|l|r|}
\hline CANADA & 2016 \% \\
\hline GENDER & 51 \\
\hline Female & 49 \\
\hline Male & \\
\hline AGE & 11 \\
\hline $18-24$ & 16 \\
\hline $25-34$ & 16 \\
\hline $35-44$ & 18 \\
\hline $45-54$ & 39 \\
\hline $55+$ & 32 \\
\hline REGION & \\
\hline $\begin{array}{l}\text { Western (Alberta, British } \\
\text { Columbia, Manitoba, and } \\
\text { Saskatchewan) }\end{array}$ & 7 \\
\hline $\begin{array}{l}\text { Atlantic (New Brunswick, } \\
\text { Newfoundland and Labrador, } \\
\text { Nova Scotia, and Prince Edward } \\
\text { Island) }\end{array}$ & \\
\hline Ontario & 23 \\
\hline Quebec
\end{tabular}

\section{Ethics}

The data is anonymized and presented in aggregate in this report. Prior to data collection, Research Ethics Board approval was obtained from two Canadian universities. Participants were shown a comprehensive consent form. Participants were offered eRewards for completing the survey, which can be transferred to various loyalty rewards programs.

\footnotetext{
2 Unfortunately, Research Now does not have panel survey participants from Northwest Territories, Nunavut, and Yukon.
} 


\section{Reporting}

The report is primarily based on two statistics: adoption rate as measured by the percentage of participants with a social media account, and usage rate as measured by the percentage of Monthly Active Users (MAU). All percentages are rounded to the nearest $1 \%$. Income is reported as the annual household income.

\section{Survey Questions}

For this report, we analyzed the following 7 questions from our survey:

\begin{tabular}{|c|c|}
\hline $\begin{array}{l}\text { Social Media } \\
\text { Adoption }\end{array}$ & $\begin{array}{l}\text { Do you have an account on the following social media sites? } \\
\text { Facebook [Yes; No; Unsure] } \\
\text { LinkedIn [Yes; No; Unsure] } \\
\text { Instagram [Yes; No; Unsure] } \\
\text { Twitter [Yes; No; Unsure] } \\
\text { Snapchat [Yes; No; Unsure] } \\
\text { Tumblr [Yes; No; Unsure] } \\
\text { YouTube [Yes; No; Unsure] } \\
\text { Reddit [Yes; No; Unsure] } \\
\text { Pinterest [Yes; No; Unsure] }\end{array}$ \\
\hline Frequency & $\begin{array}{l}\text { How often do you visit the following social media sites? } \\
\text { [Several times a day; Daily; Weekly; Monthly; Less than monthly; Never] }\end{array}$ \\
\hline Age & $\begin{array}{l}\text { What is your age group? } \\
{[18-24 ; 25-34 ; 35-44 ; 45-54 ; 55+]}\end{array}$ \\
\hline Gender & $\begin{array}{l}\text { For the purposes of this study, how would you like to be identified? } \\
\text { [Female; Male; Trans*, non-binary, two-spirit, genderqueer, other] }\end{array}$ \\
\hline Education & $\begin{array}{l}\text { What is your highest level of education earned? } \\
\text { [Some school, no degree; High school graduate; Some college, no degree; College } \\
\text { diploma; Bachelor's degree; Master's degree; Professional degree (J.D., M.D., } \\
\text { D.O., etc.); Doctorate degree] }\end{array}$ \\
\hline Employment & $\begin{array}{l}\text { Are you currently employed? } \\
\text { [Full-time; Part-time; Self-employed; Not employed] }\end{array}$ \\
\hline Income & $\begin{array}{l}\text { What is your total household income? } \\
\text { [Less than } \$ 20,000 ; \$ 20,000 \text { to } \$ 39,999 ; \$ 40,000 \text { to } \$ 59,999 ; \$ 60,000 \text { to } \\
\$ 79,999 ; \$ 80,000 \text { to } \$ 99,999 ; \$ 100,000 \text { to } \$ 119,999 ; \text { More than } \$ 120,000 \text { ] }\end{array}$ \\
\hline
\end{tabular}




\section{Funding}

This research was undertaken, in part, thanks to funding from:

Canada Research Chaires de recherche Chairs du Canada

\section{Canadà̀}

http://www.chairs-chaires.gc.ca

The Canada Research Chairs Program (CRCP) is a tri-agency (SSHRC, NSERC, CIHR) program launched in 2000. The CRCP is designed to enable Canadian universities and affiliated research institutes and hospitals to foster research excellence and to enhance their role as centres of research excellence in the global, knowledge-based economy. Chair holders are entrusted with improving our depth of knowledge and quality of life, strengthen Canada's international competitiveness, and help train the next generation of highly skilled people through student supervision, teaching, and the coordination of other researchers' work.

\section{Ryerson}

University

\section{TED}

ROGERS

SCHOOL

https://www.ryerson.ca/tedrogersschool

The Ted Rogers School of Management (TRSM) at Ryerson University is Canada's preeminent entrepreneurial-focused business school that is shaping the country's next generation of global innovators and leaders. TRSM is home to six schools of management, three innovative graduate degrees (two MBA degrees and one research-focused Master of Science in Management), and 14 cutting-edge research centres, institutes, and labs. The Ted Rogers School of Management is accredited by the Association to Advance Collegiate Schools of Business (AACSB), and is home to nearly 10,000 students and 250 industry-connected faculty members.

\section{Acknowledgments}

The authors would like to thank Jordan Kilfoy, Christine Gagnon, and Jocelyn Stéphane Cadieux for their help with the French translation of the survey and members of the Social Media Lab for their feedback on the survey design.

\section{Address}

Ryerson University Social Media Lab

10 Dundas St East

10th Floor, Suite 1002

Toronto, ON M5B 0A1 Canada 